\title{
Virtuosity, Processual Democracy and Organised Networks
}

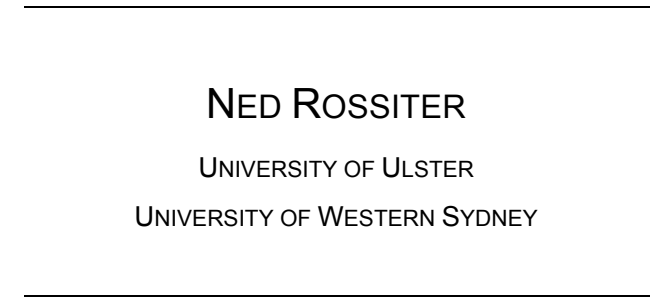

Language presupposes and, at the same time, institutes once again the 'publicly organized space'.

Paolo Virno ${ }^{1}$

\section{-INTRODUCTION}

I am a Stalinist-everyone should do as I say and think; I have no idea what I am-I don't exist ... The contradiction between these two statements signals a tension between identity politics and the politics of desubjectification. Identity operates within a regime of coding; desubjectification is a process of subjectivisation and transversality in which 'relations are external to their terms..2 There is nothing essential about a particular object, subject or thing that determines its relations. The externality of relations to their terms is what makes change possible. The identity of the Stalinist emerges from a milieu of radical contingencies. The individuation of the Stalinist is thus a potentiality that subsists within the plane of immanence. The logic of coding is part and parcel of the unforeseen capacities that define the outside of immanence.

The relationship between the overcoded subject and the process of subjectivisation is one of movement, and the movement between the two comprises the force of processuality, and a 
politics of contingency and potentiality. Stalinist subjects are everywhere-we are all Stalinists, and we also don't exist. The force of relations external to their terms operate in a manner that continuously destabilises the authoritarianism of the Stalinist subject. The process of desubjectification corresponds with the plane of immanence. This is the common from which exodus, flight and exit subsist as potentialities-potentialities that can also be found in the exploitation of cooperation that is the common of labour-power. ${ }^{3}$

The analysis of these relations is a practice of radical empiricism. ${ }^{4}$ Such an approach registers the ways in which the formation of coded subjects (identity) is an internally generative operation within the distributed plane of subjectivisation. As Antonio Negri has noted, 'from the standpoint of the body, there is only relation and process'. ${ }^{5}$ Such a diagram of relations can be transfigured upon organised networks, whose capacity to develop new institutional formations is immanent to the workings of situated socio-technical systems. ${ }^{6}$ In both cases, there is a danger of identitarianism (the Stalinist subject) or what Gary Genosko calls 'bureaucratic sclerosis' (technicist institutions) overdetermining the unforeseen creative capacity of the plane of immanence. ${ }^{7}$ I don't think it is too much a case of conceptual promiscuity to say that such an event is kept in check through the hegemonic operation between the coded subject and the constitutive force of the plane of immanence. A continuum of negotiation and re-manoeuvring characterises the tension between the desire for rule on the part of the coded entity (be it a particular subject or institutional habitus) and the potentiality of difference and proliferation peculiar to the plane of immanence.

Summarising the encounters between Félix Guattari and Italian autonomous thinkers in the late 1970s, Franco 'Bifo' Berardi explains the process of 'subjectivation' (or what I am terming subjectivisation) as a displacing of the historical legacy of the Hegalian subject. ${ }^{8}$ Bifo sees the autonomist political concept and strategy of 'refusal of work' in terms of processes of subjectivation. He considers the operaismo (workers) movements in Italy during the 1960s and 1970s as an instantiation of the larger international transition from Fordism to post-Fordism:

Refusal of work does not mean so much the obvious fact that workers do not like to be exploited, but something more. It means that the capitalist restructuring, the technological change, and the general transformation of social institutions are produced by the daily action of withdrawal from exploitation, of rejection of the obligation to produce surplus value, and to increase the value of capital, reducing the value of life.

Bifo is resolute that it was the process of autonomisation among workers that 'provoked' the capitalist response of institutional and market deregulation. As much as workers may have escaped the industrial time of the factory, capital was awakened to new possibilities of managing time. The flexibilisation of labour coupled with advances in information and communication 
technologies enabled capital to intensify the process of economic globalisation. For Bifo, the transformation in the socio-technics of labour and production amounts to a 'capitalist takeover of social desire', resulting in an 'alliance between recombinant capital and cognitive work'. As labour-power has become integrated with the deterritorialising capacities of information technologies, the effectiveness of political organisations such as unions has, in many instances, declined. The result of this has been a tendency toward what I have called 'disorganised labour' as distinct from 'immaterial labour'. ${ }^{9}$

It is within such post-Fordist, informationised settings that the problematic of democracy has become renewed. Following the thesis advanced by Paolo Virno, I start with the premise that the decoupling of the state from civil society and the reassertion of the multitudes over the unitary figure of 'the people' coincides with a vacuum in political institutions of the state. ${ }^{10}$ Against Chantal Mouffe's promotion of an 'agonistic democracy', I argue that the emergent idiom of democracy within networked, informational settings is a non- or post-representative one that can be understood in terms of processuality. ${ }^{11}$ I maintain that a non-representative, processual democracy corresponds with new institutional formations peculiar to organised networks that subsist within informationality. In contrast, Mouffe has a faith that is still too deeply invested in political institutions of the modern state form and her agonistic democracy depends heavily on the institutional legitimacy of the state. As states across Western liberal democracies have increasingly disengaged from discourses of political and social citizenship in favour of the oxymoronic notion of individualised 'shareholder-democracy', the legitimacy of the state as a complex of representative institutions is only brought into greater question.

More significant for this paper, which seeks to advance a political and media philosophy of processuality, is Mouffe's failure to recognise how media forms and institutions and their attendant practices have interpenetrated the ordinary lives of people, most especially since the creeping departure from the early 1980s onwards of the welfare state and its social-political institutions. As I have argued elsewhere, it is important not to confuse the transformation of the state with its disappearance. ${ }^{12}$ Rather, we are witnessing the ongoing structural transformation of state apparatuses in ways that reproduce the patterns of change seen in a plethora of corporate, cultural and not-for-profit institutions. The gestures and protocols of transparency once associated with and expected from public institutions have given way to a corporate culture of secrecy. The privacy that once, quite paradoxically, 'deprived'13 individuals of a voice and public presence has now become inverted: life within a reality-media complex voraciously extracts people from under the radar, extending the socio-technical capacities of the mediasphere as the definitive organ of social and cultural legitimation and value formation. Similarly, it has become routine practice for the state to tender its social services and fiscal management to firms that provide the best post-political packages for career politicians while, 
more insidiously, retaining the right of privacy common to corporate law-the 'confidentiality agreement'-that serves the interests of protecting corporate-state negotiations. Whereas privacy within an era of the bourgeois public sphere deprived the individual of a public presence, perversely, privacy in an epoch of neo-liberalism functions to enhance the security of the corporate-state nexus.

Such changes in the way social relations are organised have not advanced toward some more enlightened, rational stage of social-political development. Instead, on the one hand, they have resulted in capital extending its destructive capacity with a massive intensification in environmental degradation associated with new techniques in agricultural and industrial production, the expansion of urban infrastructures and the demands by consumers for greater diversity of the same; in generations of people being left to live in poverty; and in technological advancements in the military-entertainment complex, which have fuelled the political economy of corporate governments as they impose their domestic agendas on minor states. Yet, on the other hand, the transformation of social relations and the techniques of organisation more generally have coincided in recent years with a re-emergence and reassertion of the multitudes-a mutable movement of movements whose tactics of social-political intervention and cultural production have been greatly facilitated by the widespread availability of relatively cheap new media technologies associated with the Internet. Mailing lists, web campaigns, realtime audio-streaming, the mobile phone and blogs have played key roles in shaping the actions of tactical media. And, it should be said, such technologies have also benefited the interests of global capital. The difference between these two endeavours is one that runs along the lines of values, interests, constituencies and desires. ${ }^{14}$ Hope is reasserting its force. The re-emergence of the multitudes as the inventors of another possible world, along with the gradual dissolution of supranational governing agencies such as the World Trade Organisation (WTO) and the increasing incapacity of powerful states such as the USA and Britain to manage their pursuits of crisis, are all part of a proliferation of signals that indicate the hegemony of neo-liberalism is on the wane.

Against this backdrop, this paper seeks to resituate Mouffe's notion of agonistic democracy as a radical pluralism within networked media ecologies. Such a shift necessitates new models with which to think and enact the possibility of radical democracy within a digital terrain. I deploy the notion of media translation as the figurative passage that ushers in the conditions for a processual democracy within network societies. With reference to the limits of both tactical media and traditional institutional structures, the paper argues how the persistence of organised networks as new institutional forms depends upon addressing two key problematics: sustainability and scale. This paper advances an argument for political activists to make a strategic turn in order to raise the stakes of what it means to live-and, indeed, how we live- 
within informational societies. In as much as processuality corresponds with socio-technical networks of media-in-translation, so too the multitudes-as a mutable, proliferating sociotechnical expression of life-hold the potential to create polities that support the ongoing formation of life as an affirmative force.

Finally, the task of this paper is to identify how and why an institutional turn is now required among media activists. Of course there can be no definitive program for such a shift. Nevertheless, emergences can be detected. 'Movement', writes Deleuze, 'is translation in space. Now each time there is a translation of parts in space, there is also a qualitative change in the whole. ${ }^{15}$ Transformations register on the radar of this media-informational present and hold the capacity to translate across socio-technical networks in unforeseen ways. Pure virtuality.

\section{-Virtuosity and Processual Democracy}

Surplus value is based on excess-an excess of labour-power. With a surplus of labour-power (unemployment), the cost of production decreases and profit rises. Labour-power, however, is predicated on cooperation, and herein lies the potential for transformation, since cooperation subsists in the plane of immanence, the common. The capacity for the articulation of other values, and the mobilisation of other affects is immanent to the surplus value of labour-power. Surplus value can also be understood as an individuation transduced from the pre-individuality of cooperation, of the 'general intellect'. This is what Negri identifies as the 'ontology of the multitudes'. The cooperation peculiar to the surplus value of labour-power grants what Hardt and Negri identify, and had previously dismissed, as the class dimension to the emergent sociotechnical form of the multitudes, since exploitation conditions the possibility of cooperation. ${ }^{16}$ The multitudes are co-extensive with cooperation. Since the surplus value of capital is parasitic upon and conditioned by cooperation, so too can the multitudes (cooperation) be understood as a class concept.

The organised network is a potentiality co-extensive with the process of becoming instituted. Virtuosity, as the absence of an 'extrinsic product', institutes the political potential of organised networks. ${ }^{17}$ The virtuosos 'activity without an end product' is at once ordinary and exceptional: ordinary in the sense that 'the affinity between a pianist and a waiter', as anticipated by Marx, comprises the common of wage labour in so far as 'the product is inseparable from the act of producing'; exceptional in the sense of the potential that subsists within performances with no end product holds the capacity of individuation-of transformation of the common-into singularities with their own distinct universes of sensibility, logics of sensation, regimes of codification. ${ }^{18}$ Institutions (coded formations) consist of practices and affects, techniques and sensations. Institutions emerge within the interplay between the plane of immanence and the plan of organisation. Within the cooperation common 
to surplus value's exploitation of labour-power resides the potential for new relations, new institutions, new socialities.

Yet can we become democratic? Since-following Virno, a Deleuzo-Foucauldian line, along with a strand within political philosophy and international relations-the activities of the multitudes are exterior to the idea of representation, which is the key procedure by which modern democracy figures itself, how might democracy constitute itself within contemporary socio-technical networks? To ask this question is also to ask whether the mobilisation of capacities within socio-technical networks-or processes of translation which might incorporate computer systems, software designers, cognitive workers, and so on-can produce political institutions, or arrangements of the social. Moreover, and following Mouffe, it is to ask whether the realm of networks consist of or are articulated with a material dimension, hence constituting a 'politics', which Mouffe defines in her book The Democratic Paradox as 'the ensemble of practices, discourses and institutions that seek to establish a certain order and organise human coexistence in conditions that are always potentially conflictual because they are affected by the dimension of "the political"'. ${ }^{19}$

In other words, to ask the question of democracy with respect to actors, networks, processes of translation and politics is, at a fundamental level, to inquire into the power relations that condition the formation of the social. If the modern is underpinned by processes of translation, which might also be understood as 'border wars', then it might be said that the multitudes, as 'an infinity of singularities' that brings boundaries into question, inhabit the abstracted spaces of the modern. ${ }^{20}$ As I discuss below, part of this 'border-work' of the multitudes corresponds with what Virno identifies as the re-emergence of the multitudes as a force with presence in a post-Fordist era of capitalism. First, however, it is helpful to further distinguish the political concept of the multitude from the logic of representation. As Negri explains:

Most generically, the multitude is diffident to representation because it is an incommensurable multiplicity. The people is always represented as a unity, whilst the multitude is not representable, because it is monstrous vis-à-vis the teleological and transcendental rationalisms of modernity. ${ }^{21}$

Virno suggests that the communicative performance of the multitudes constitutes 'the feasibility of a non-representational democracy, ${ }^{22}$ Virno is elusive when it comes to developing that proposition. A non- or post-representational democracy is one that no longer operates within constitutive framework of the nation-state and its associated institutions and civil society organisations. This is something Mouffe's 'agonistic democracy' is not able to confront. While Mouffe correctly wishes to go beyond rational consensus, deliberative models of liberal democracy, her proposition that agonistic democracies negotiate the antagonisms that underpin 
sociality is nevertheless one that is predicated on the maintenance of the state as modern complex of institutions. Mouffe has not made the passage into the post-Fordist state and its connection with capital's modes of informatised production and flexible accumulation. The informatisation of social relations is nowhere to be found in Mouffe's thesis on agonistic democracy. As such, Mouffe is unable to describe the new modes of sociality, labour and politics as they are organised within network societies and information economies. Even so, her notion of an agonistic democracy-like Virno's non-representational democracy—can be retained, but only, I would suggest, when they are recast in terms of what I call a processual democracy. How might the politics of networks as they operate within informationalised institutional settings be understood in terms of a processual democracy?

A processual model of socio-technical operations inquires into the movement between the conditions of possibility and that which has emerged within the grid of signs, codes and meanings-or what Deleuze understands as the immanent relationship between the plane of consistency and the plan of organisation. ${ }^{23}$ Conditions of possibility are different in kind from that which comes to be conditioned. There is no resemblance or homology between the two. Think back to the difference between the process of subjectivisation and the Stalinist identity. There are relations between the two, but they are not of the same. External forces are not grids whose stabilising capacity assures the intelligibility of a problematic as it coalesces within a specific situation.

Yet despite these dissonances, networks are defined by-perhaps more than anythingtheir organisation of relations between actors, information, practices, interests and sociotechnical systems. The relations between these terms may manifest at an entirely local level, or they may traverse a range of scales, from the local to the national to the regional to the global. Whatever the scale may be, these fields of association are the scene of politics and, once they are located within institutional settings, are the basis of democracy in all its variations. A processual democracy goes beyond the state-civil society relation. That relation no longer exists. Processual democracies necessarily involve institutions, since institutions function to organise social relations. This isn't to say that in and of themselves the modulation of networks somehow automatically result in democracy. But it is to suggest that the processes by which networks undergo a scalar transformation signal the emergence of new institutional forms that are shaping politics as a non-representational idiom.

The potential of processual democracies is underpinned by the informatisation of social relations. Franco 'Bifo' Beradi's model of the infosphere and the psychosphere is a useful one to describe the complex settings within which new polities may emerge. ${ }^{24}$ Bifo's conception of the infosphere as a technical, digital coding of data whose unilinear flows 'intermingle' with the unstable, recombinatory filter of the psychosphere is, however, only partially right. ${ }^{25}$ The 
infosphere is, of course, much more complex. Think of the uneven geography of information, the political economy of root servers and domain names, and the competing interests surrounding Internet governance debates and policy making. The infosphere thus not only 'intermingles' with the psychosphere, it is inseparable from it: put in different terms, the real is always inscribed or present within the symbolic as an antagonism or trauma. The infosphere is shaped by background noise, which Michel Serres defines as the 'absence of code'. ${ }^{26}$ Processuality-the relationship between coding and conditions of possibility-incorporates background noise as a constitutive outside. $^{27}$

A processual democracy unleashes the unforeseen potential of affects as they resonate from the common of labour-power. Processual democracies also continue to negotiate the ineradicability of antagonisms. Their difference lies in the affirmation of values that are internal to the formation of new socialities, new technics of relations. Certainly, they go beyond the limits of resistance and opposition-the primary activity of tactical media and the 'anticorporatisation' movements. This is not to dispense with tactics of resistance and opposition. Indeed, such activities have in many ways shaped the emergence of civil society values into the domain of supranational institutions and governance, as witnessed in the recent World Summit on the Information Society (WSIS) debates. ${ }^{28} \mathrm{~A}$ radical adaptation of the rules of the game is a helpful way of thinking the strategic dimension of processual democracies.

\section{-Organised Networks}

My argument is that in order for networks to organise mobile information in strategic ways that address the issues of scale and sustainability, a degree of hierarchisation, if not centralisation, is required. Let's not forget that for all the anti-state rhetoric of anarchists, they, like many 'radical' outfits, are renowned for being organised in highly hierarchical ways-typically around the cult of the alpha-male. The point is that such organisation occurs within the media of communication. Herein lies the difference between the organised network and the networked organisation. ${ }^{29}$ The latter consists, quite simply, of networking traditional institutional settings. The architectural configuration of the building provides the skeletal framework within which electronic and social networking is negotiated. Certainly, this is not as entirely straightforward as bringing in the stooges to refit the shell, like we see in all those house-renovation/lifestyle TV shows that appeal to our aspirational fantasies. No doubt many people have got stories of, if not directly experienced, the difficulties faced by many workers who over the past couple of decades had to adjust to the computerisation of work environments. ${ }^{30}$ Such changes require the acquisition of new skills and a transformation of habits. And this affects many, from the cognitariat to those engaged in more menial forms of labour. Nonetheless, the distinction remains: the techniques of governance within the networked organisation, unlike the organised 
network, do not place a primacy on the media of communication. Or rather, bricks and mortar prevail as the substrate within which communication and socio-technical relations are managed.

Organised networks, on the other hand, hold an entirely different range of potentialities with regard to the orchestration of socio-technical relations. While organised networks principally consist of online forms of communication such as mailing lists, IRCs or newsgroups, it would be a mistake to overlook the importance of face-to-face meetings-or 'fleshmeets' or 'meetspaces', as the 1990s style cyber-speak would have it. Such occasions are crucial if the network is to maintain momentum, revitalise energy, consolidate old friendships and discover new ones, recast ideas, undertake further planning activities, and so on. Different spaces, different temporalities, different media of communication, different mediations of sociality. This is mediology. Translation is the media logic that makes possible a continuum of relations between one socio-technical form of mediation and another. There is no a priori smoothness that defines a continuum of relations. ${ }^{31}$ Frequently enough tensions are going to prevail. Antagonisms may indeed be immanent to the process of translation. Any media translation involves an engagement with 'the political'. Such is the relationship between the plane of consistency and the plane of organisation. ${ }^{32}$ Both coexist within a field of sociality. It helps, then, to invent a media theory of these kind of relations as a way of making intelligible and actionable the politics of informationality.

It is time to make a return to and reinvestment in strategic concepts, practices and techniques of organisation. Let's stop the obsession with tactics as the modus operandi of radical critique, most particularly in the gross parodies of de Certeau one finds in US-style cultural studies. ${ }^{33}$ Don't get me wrong-I'm not suggesting that the time of tactical media is over. Clearly, tactical media play a fundamental role in contributing to the formation of radical media cultures and new social relations. If one starts with the principle that concepts and practices are immanent to prevailing media forms, and not somehow separate from them, it follows that with the mainstream purchase of new media forms such as the Internet come new ways in which relations of production, distribution and consumption are organised. An equivalence can be found in the shift from centralised Fordist modes of production to decentralised post-Fordist modes of flexible accumulation. Strategies within the spatio-temporal peculiarities of the Internet are different from strategies as they operate within broadcast communications media. The latter ultimately conceives the 'audience-as-consumer' as the end point in the food chain of media production, whereas the former enables the 'user' to have the capacity to sample, modify, repurpose and redirect the social life of the semiotic object. Moreover, there are going to be new ways in which institutions develop in relation to Internet-based media culture. How such institutions of organised networks actually develop in order to obtain a degree of sustainability 
and longevity that has typically escaped the endeavours of tactical media is something that is only beginning to become visible.

Ultimately, the networked organisation is distinguished by its standing reserve of capital and its exploitation of the potentiality of labour-power. Such institutions are motivated by the need to organise social relations in the hope of maximising 'creativity' and regenerating the design of commodity forms that have long reached market saturation. ${ }^{34}$ Paolo Virno's observation that post-Fordist 'labor has acquired the traditional features of political action'thus reversing Hannah Arendt's thesis that politics is subsumed into the experience of labouris a forceful one evidenced within the informational industries by the migration of tactical media style practices into more traditional institutional settings of both capital and its substrate, the neo-liberal state. ${ }^{35}$ Virno notes that the previously distinct and traditionally indisputable boundaries between labour, action and intellect have now become indiscernible within postFordist modes of production. ${ }^{36}$ As Virno writes: 'the world of so-called post-Fordist labour has absorbed into itself many of the typical characteristics of political action ... this fusion between Politics and Labour constitutes a decisive physiognomic trait of the contemporary multitude, ${ }^{37}$ This move of the multitudes into the sphere of post-Fordist production clearly signals the operation of the 'constitutive outside' ${ }^{38}$ But there are vital issues at stake here: issues of how a life is to be constituted, how it is to be invented within the network of relations that populate the common of creative potentiality. The clear danger is that politics, as 'a difference that makes a difference', becomes nothing more than market strategies aimed at commodity differentiation. ${ }^{39}$

By contrast, the kind of emergent organised networks that I'm speaking of are notable for the ways in which information flows and socio-technical relations are organised around site specific projects that place an emphasis on process as the condition of outcomes. The needs, interests and problems of the organised network coincide with its emergence as a sociotechnical form, whereas the traditional modern institution has become networked in an attempt to recast itself while retaining its basic infrastructure and work practices, clunky as they so often are. Strangely enough the culture of neo-liberalism conditions the emergence of the organised network. The logic of outsourcing has demonstrated that the state still requires institutions to service society. Scale and cost were the two key objections 'econorats' and servants to neoliberalism responded to. Forget about ideology. These bureaucrats are highly neurotic, obsessive-compulsive types. They hate any trace of disorder and inefficiency, and the welfare state embodied such irritations. The organised network can take advantage of such instituted pathologies by becoming an educational 'service provider', for instance. The key is to work out what values, resources and capacities distinguish your network from the MIT model of 'free courseware'. ${ }^{40}$ The other factor is to work out a plan for sustainability-a clear lesson from the dotcom era. With the multitudes situated in post-Fordist modes of production, an opportunity 
presents itself-the opportunity to mobilise what Virno calls the 'pure potential' of labourpower as an ethico-aesthetic force into the process of eradicating capital's predisposition to marshal the mode of production toward 'effective labour' as a service provision.

\section{-TRANSLATION, TRANSDUCTION AND INDIVIDUATION}

I have suggested that code is a language whose precondition is the possibility for meaning to be produced. Similarly, and like the relationship between the plane of immanence and the plane of organisation, individuation consists of a process that Deleuze, Virno and Mackenzie call a preindividual reality: 'something common, universal and undifferentiated'. ${ }^{41}$ Singularities emerge out of common capacities: of language, of perception, of production. ${ }^{42}$ Transduction is the complex of forces through which the process of individuation translates pre-individual realities-that which is common-into singularities. As Adrian Mackenzie explains:

The main point is that transduction aids in tracking processes that come into being at the intersection of diverse realities. These diverse realities include corporeal, geographical, economic, conceptual, biopolitical, geopolitical and affective dimensions. They entail a knotting together of commodities, signs, diagrams, stories, practices, concepts, human and non-human bodies, images and places. They entail new capacities, relations and practices whose advent is not always easy to recognise ... Every transduction is an individuation in process. ${ }^{43}$

The organised network as a new institutional formation is another example of the stabilising capacity of transductive forces. The primary difference, however, is that organised networks are shaped by the power of socio-technical needs, interests, affects and passions that hold the potential to translate into new institutional forms. All communication is a process of translation. Networks are uneven, heterogeneous modulations and combinations of communication in and through which translation is intrinsic to the connectivity of information as it encounters technical, social, political, economic and cultural fields of articulation, negotiation and transference. Translation, then, is about making connections between seemingly incommensurate things and objects. Translation conditions the possibility of communication, transversality, transduction, intensity and individuation between different systems. ${ }^{44}$ From the connection emerges a new logic, a new sensibility and new capacities. At a very basic level, the logic of networks is the process of connectivity.

Networks have the capacity of transduction, which Adrian Mackenzie, via Gilbert Simondon, describes as a process of ontogenesis 'in which a metastability emerges' within biological and socio-technical systems. ${ }^{45}$ Or as Andrew Murphie puts it, 'transduction translates intensities so that they can be brought into individuating systems'. ${ }^{46}$ The form of organised networks provides a mutable architecture in which matter is temporarily arrested within a continuum of 
differentiation and individuation. Transductive forces subsist within the relation between form and matter. The organised network can be considered as a new institutional actant whose political, economic and expressive capacities are shaped and governed by the metastability of the network system. The intelligibility of such arrangements, relations and informational flows is thus most accurately summarised by a theory of translation which incorporates processes of transduction. Translation is truly a concept of praxis. It is part and parcel of every network. Transduction conditions the possibility of organised networks as emergent institutional entities.

At the start of this paper I made passing reference to the way in which the 'citizen-subject' has been supplanted by the individual who engages not with a democratic state but a shareholder-democracy. It's important to carefully distinguish the sense of individualisation evoked here from the Simondonian idea of individuation. The former has been addressed by sociologists such as Ulrich Beck and Scott Lash in terms of individual subjects engaged in the self-management of 'risk' peculiar to the era of 'second modernity', while the latter, as discussed by Deleuze, Mackenzie and Virno, is understood as a processual ethico-political cartography of potentiality. Individuation is a process by which a multitude of subjectivities emerge from that which is common: living labour, life, general intellect, cooperation, sociality, exploitation by capital, and so on. The organised network carries the potential for the individuation of subjectivities into new institutional forms. This process is one of political invention. Individuals become individuated, organising as multitudes, creating the potential for the emergence of instituted singularities. Beck and Lash, on the other hand, reduce and thus dismiss the possibility of institutional life as specific to an industrial era of risk society, or 'first modernity', which has been surpassed by an era of 'second modernity' characterised by disorganisation, informationisation and networks.

Beck initiates his book What is Globalization? with a rendition of the bleak outlook held by 'postmodernists' and neo-liberal ideologues alike, who, by Beck's reckoning, associate the crisis of democratic polities with the erosion of traditional institutional forms. This shift arises as a result of 'the secular trend of individualization', which effects a loosening of social bonds. ${ }^{47}$ Accompanying this trend, according to Beck's summation of the general discourse on economic globalisation, is a society that has lost its 'collective self-consciousness and therefore its capacity for political action'. ${ }^{48}$ Beck dismisses this fatalistic scenario in which the totalising effects of economic globalisation debilitate political action, though he sees such a discourse as little more than the incapacity of people to advance out the imbroglio of some kind of false-consciousness (9). Beck's faith in the possibility of an alternative political culture is evidenced by the political actions undertaken by global civil society movements, which operate within a different dimension or layer of what he refers to as the experience of 'globality'—or a 'world society' 
conceived of as a 'multiplicity without unity', as distinct from processes of economic 'globalisation' and the neoliberal ideology of 'globalism'. 49

Certainly, Beck is correct to observe that the remodelling of the state within a neo-liberal ideology has seen a shift of the modern state form away from the social. Yet he is mistaken, I would maintain, to see the decoupling of sociality from politics as corresponding with a decline in institutional forms and their techniques of organising social relations within political frameworks. Not only does Beck overlook the continued purchase the state has on the management of everyday lives - think, for example, of the legal authority institutions of the state have in both the movement of peoples and the flow of information (for example, the WTO's TRIPS Agreement in 1995 and the bond with member states, enhanced national security measures with regard to the movement of individuals, and free-trade agreements that determine the composition of cultural commodities)-but, more significantly, he greatly underestimates the fundamental importance that institutions in a general sense play in the organisation of social relations. Moreover, in terms of how to begin both theorising and undertaking political action in a sustained manner within an informational society, the futility of Beck's position, by my reading, lies in its failure to recognise and imagine the ways in which the multitudes incorporate a strategic potential that can manifest in the creation of new institutional forms.

Lash arrives at a similar conclusion to Beck. Lash considers the shift from 'first modernity' to 'second modernity' as paralleling the decline of organisations (such as the firm, the institution, unions and the family) and the emergence of disorganisations (such as youth subcultures, criminal gangs, computer designers and the 'neo-family'). ${ }^{50}$ There is an implicit assumption here that, firstly, 'disorganised capitalism' is indeed disorganised-capital, here, is much better understood in my view in terms of what David Harvey calls 'flexible accumulation'. ${ }^{51}$ The rise of transnational capital has not at all meant that the firm or institution loses its hegemony as an architectonic form involved in the management of social relations and economic production. Far from it. Disorganised capitalism simply means that capital is organised differently. The primary activity by capital of organising labour-power in order to effect production, distribution and exchange has not disappeared. Rather, it is dispersed and relocated on the basis of currency exchange rates, the cost of labour, taxation rates, government incentives (or, more properly, corporate welfare), levels of technical infrastructure and supporting service industries. Herein lies the flexibility of capital. Secondly, Lash assumes precisely the linear model that he seeks to reject, claiming that disorganised capital results in disorganised sociality. Disorganised capital is capital organised by different means. Similarly, 'disorganised sociality', consists, at least within the logic of informationality, of social relations organised in ways that are immanent to prevailing communications media. Lash is correct on this point, albeit without 
comprehending the ways in which a constitutive outside operates within the plane of immanence. ${ }^{52}$ The overdetermining binary system by which Lash secures his logic of disorganisations is worth quoting at length:

Organizations and the 'power resources' that reside in organizations stand thus in no way in contradiction to the individualization process of high modernity. Indeed, individualization is the complement, the other side of this organizational power. Organizational power is the condition of existence of individualization, and individualization is the condition of existence of organizations ... What I want to argue, however, is that organizations and their accompanying power, and indeed individualization as we know it, are decaying social forms ... What is emergent is not so much organizations as disorganization, not so much individualization as sociality, and not so much power as violence ... Disorganizations are not the absence of organization, but the decline of organizations. The decline of organised capitalism does entail a decline in organization and a rise in individualism. But it also entails a rise in certain forms of sociation that are non-organizational, indeed often non-institutional. So disorganizations are not the absence of sociation, but particular forms of sociation. They are chaos, not chaotic ... Disorganizations presume a certain level and a particular mode-or should we say singular mode-of individualization, though they are somehow at the same time much more collective than are organizations. Disorganizations presume a different mode of individualization than organizations, they presume a non-utilitarian, non-strategic, non-identical mode of individualization ... Disorganizations are perhaps less hierarchical than horizontal. They are anti-system - they are too open to interference and invasion from the environment to be systems ... 53

To dismiss the technics of organisation enlisted by the new social movements is to rob them of vitality, and of the great urgency that now beckons the multitudes to register their political potential on another scale, and with a capacity for sustainability that has hitherto evaded this common plurality of living labour. Or as Paul D Miller, aka DJ Spooky, puts it, 'What differentiates today from yesterday is the scale and scope of the paradigm'. ${ }^{54}$ Just as the pre-individual is common to the process of individuation, whereby capacities are that which are shared and coextensive, so too the organised network as a new institutional form corresponds with the preindividual as that which is held in common. Let me unpack this. If political and corporate institutions within an industrial era of 'first modernity' typically functioned to de-individualise the worker in terms of a common unit to be managed, then such institutions reify the worker as a mass and incapacitate the individual through the conformist unity of 'effective labour', 'the 
people' or 'the citizen'. In other words, the potential of labour-power as a common set of capacities-what Hardt and Negri understand as linguistic, communicational and affective networks' -is subordinated to the mode of production. ${ }^{55}$ Virno explains: 'The capitalist production relation is based on the difference between labor-power and effective labor. Laborpower, I repeat, is pure potential, quite distinct from its correspondent acts' ${ }^{56}$ Moreover, it is this potential of labour-power that is of primary value for the capitalist. Virno again:

Potential is something non-present, non-real; but in the case of labour-power, this non-present something is subject to the laws of supply and demand. Capitalists buy the capacity for producing as such ('the sum of all physical and intellectual aptitudes which exist in the material world'), and not simply one or more specific services. ${ }^{57}$

Such a notion of labour-power suggests that the 1960s and 1970s autonomist mantra and radical worker movement's political strategy of a 'refusal of work' is perhaps more clearly expressed in terms of 'a refusal of potentiality' as it is subsumed by capital. Thus the key strategy for the multitudes is to secure their production of potentiality and direct it toward selfgenerating ends. The pure potential of labour-power turns on an important distinction that Virno reads into the 'mode of production'. Not only is 'mode of production' to be understood as 'one particular economic configuration', writes Virno, 'but also [as] a composite unity of forms of life, a social, anthropological and ethical cluster, ${ }^{58}$ The process of individuation subsists within and emerges from this commons as a plurality of differences. A mode of producing. The combinations, arrangements and expressions of these relations constitutes an 'ethical cluster'. An event. To be in relation is to become ethical. A productive force is at work. Individuation is a process of becoming individual within a multiplicity of relations. Thus, 'the individual is not just a result, but an environment of individuation. ${ }^{59}$ Within the socio-technical environment of informationality emerges the organised network as a potentiality coextensive with the process of becoming instituted.

\section{-CONCLUSION}

While I have been arguing for the need for organised networks to create-or what Franco 'Bifo' Berardi calls the unforeseen capacity to invent-new institutions, let me emphasise that such activity is not some kind of end in itself. ${ }^{60}$ 'It is not a question of "seizing power"', as Virno writes of the force of the multitude, 'of constructing a new State or a new monopoly of decision making; rather, it has to do with defending plural experiences, forms of non-representative democracy, of non-governmental usages and customs. ${ }^{61}$ The invention by the multitudes of new institutional forms, and the persistence of their attendant practices, is part of a process that exists within a larger and more complex field of critical Internet cultures. Such developments can only occur 
when the networks are attentive to the technological composition of communications media as that which consists of socio-technical relationships. ${ }^{62}$

In order for tactical media and list cultures to organise as networks that have multiple institutional capacities, there has to be-first and foremost-an intellect, passion and commitment to invention. There has to be a desire for socio-technical change and transformation. And there needs to be a curiosity and instinct for survival to shift finance capital to places, people, networks and activities that hitherto have been invisible. The combination of these forces mobilises information in ways that hold an ethico-aesthetic capacity to create new institutional forms that persist over time and address the spectrum of socio-political antagonisms of information societies in a situated fashion.

The concept of the multitudes is a seductive one. It presents the 'radical intellectual' with an image of passion, change and, yes, even unity, which corresponds with an image of 'radical politics' as seen in the news media. The terribly dull thing about the multitudes is that 'they'-as a plurality of differences, a movement of movements, a performance 'with no end-product'-are not composed of 'enlightened', 'ordinary' people who enact the fantasies of the radical intellectual. In many ways, the multitudes are a distribution of disorganised, individualised workers-in the sense that Beck and Lash mean by this term-who possess a potential to encounter the transductive force of individuation that shifts the individualisation of labourpower into a singularity with networked capacities. My argument throughout much of this paper has been that such a transformation is conditioned by a capacity to become organised.

I'd like to thank Chris Healy for his guidance in the revision of this essay.

Ned Rossiter is Senior Lecturer in Media Studies (Digital Media) at the Centre for Media Research, University of Ulster, and Adjunct Research Fellow at the Centre for Cultural Research, University of Western Sydney. Ned also co-facilitates fibreculture, a network of critical Internet research and culture in Australia.<n.rossiter@ulster.ac.uk>

\footnotetext{
-NOTES

1 Paolo Virno, A Grammar of the Multitude, trans. James Cascaito Isabella Bertoletti, and Andrea Casson, forward by Sylvère Lotringer, Semiotext(e), New York, 2004.

2 See Gilles Deleuze, Empiricism and Subjectivity: An Essay on Hume's Theory of Human Nature, trans. Constantin V Boundas, Columbia University Press, New York, 1991. See also Gilles Deleuze and Claire Parnet, Dialogues II, trans. Hugh Tomlinson, Barbara Habberjam and Elliot Ross Albert, Continuum, London and New York, 2002.
} 
3 See Antonio Negri, 'Public Sphere, Labour and Multitude', trans. Arianna Bove, MakeWorld Paper, no. 3, 2003 , p. 4.

Also available at <http://www.makeworlds.org/?q=node/view/11>.

4 For an example of how a Deleuzian radical empiricism can operate within media theory, see Ned Rossiter,

'Processual Media Theory', symploke, vol. 11, nos. 1/2, 2003, pp. 104-31.

5 Antonio Negri, 'Towards an Ontological Definition of the Multitudes', trans. Arianna Bove, Makeworlds Paper, no. 4, 2004, <http://www/makeworlds.org/book/view/104>.

${ }^{6}$ Because this paper is an attempt to set out some of the theoretical, political and economic parameters within which organised networks emerge, I do not have the space required to outline case studies of organised networks. Briefly, I would suggest two examples that correspond to how I'm conceiving organised networks here: Sarai, a Delhi based media centre <www.sarai.net $>$; and Fibreculture, a network of Internet research and culture in Australasia $<w w w$.fibreculture.org $>$. In their own ways, the conditions of possibility for the emergence of these organised networks can be understood in terms of the constitutive outside. Both networks address specific problems of sociality, politics, and intellectual transdisciplinarity filtered-at least in the case of fibreculture-through a void created by established institutions within the cultural industries and higher education sector.

${ }^{7}$ Gary Genosko, 'Félix Guattari: Towards a Transdisciplinary Metamethodology', Angelaki, vol. 8, no. 1, 2003, p. 33.

8 Franco 'Bifo' Berardi, 'What is the Meaning of Autonomy Today?', republicart, September 2003,

<http://www.republicart.net/disc/realpublicspaces/berardi01_en.htm>.

${ }^{9}$ See Ned Rossiter, 'Report: Creative Labour and the role of Intellectual Property', Fibreculture Journal, no. 1, 2003,

$<$ http://journal.fibreculture.org/issue1/issue1_rossiter.html>.

10 Virno.

11 Chantal Mouffe, The Democratic Paradox, Verso, London, 2000.

12 See Ned Rossiter, 'Modalities of Indigenous Sovereignty, Transformations of the Nation-State, and Intellectual Property Regimes', Borderlands E-Journal: New Spaces in the Humanities, vol. 1, no. 2, 2002,

<http://www.borderlandsejournal.adelaide.edu.au/issues/vol1no2.html>. See also Ned Rossiter, 'Whose Democracy? Information Flows, NGOs and the Predicament of Developing States', Dark Markets: Infopolitics, Electronic Media and Democracy in Times of Crisis, International Conference by Public Netbase/t0, Muesumsplatz, Vienna, 3-4 October 2002, <http://darkmarkets.t0.or.at/materials/abstract_rossiter.htm>.

13 See Virno, p. 24.

14 Virno also recognises the similarities between these two formations: "The notion of the multitude seems to share something with liberal thought because it values individuality but, at the same time, it distances itself from it radically because this individuality is the final product of a process of individuation which stems from the universal, the generic, the pre-individual'. (76) I unpack the distinctions between individuality, its attendant process of individualisation, and individuation below.

15 Gilles Deleuze, Cinema 1: The Movement Image, trans. Hugh Tomlinson and Barbara Habberjam, University of Minnesota Press, Minneapolis, p. 8.

${ }^{16}$ Michael Hardt and Antonio Negri, Multitude: War and Democracy in the Age of Empire, Penguin Press, New York, 2004. See also Negri, 'Towards an Ontological Definition of the Multitudes'. For an argument that identifies class as the primary antagonism and basis for intervention within informational politics, see McKenzie Wark, A Hacker Manifesto, Harvard, Cambridge, Mass., 2004

17 Virno, p. 52.

18 Virno, p. 68.

19 Mouffe, p. 103.

20 See J Macgregor Wise, Exploring Technology and Social Space, Sage, Thousand Oaks, Cal., 1997, p. 43; Antonio Negri with Anne Dufourmantelle, Negri on Negri, trans. MB DeBevoise, Routledge, London and New York, 2004, p. 124.

${ }^{21}$ Negri, 'Towards an Ontological Definition of the Multitudes'.

${ }^{22}$ Virno, p. 79.

${ }^{23}$ See Brian Massumi, Parables for the Virtual: Movement, Affect, Sensation, Duke University Press, Durham and London, pp. 1-25.

${ }^{24}$ Franco 'Bifo' Berardi, 'Media, Image, Dispositif', seminar presentation, University of Technology, Sydney, 9 September 2004, and published this issue of Cultural

Studies Review (vol. 11, no. 2, 2005).

${ }^{25}$ I am paraphrasing Bifo's conception of the infosphere and psychosphere, based on my notes from the seminar presentation and the abstract of the paper. 
${ }^{26}$ Michel Serres, The Birth of Physics, trans. Jack Hawkes, Clinamen Press, London, 2001.

${ }^{27}$ See Rossiter, 'Processual Media Theory'. See also Ned Rossiter, 'Creative Industries, Comparative Media Theory, and the Limits of Critique from Within', Topia: A Canadian Journal of Cultural Studies, no. 11, 2004, pp. 21-48.

${ }^{28}$ For background information and critical reports on the WSIS, see $<$ http://www.itu.int/wsis $>,<$ http://www.wsisonline.org>, <http://www.unicttaskforce.org>, <http://www.apc.org>, <http://www.ssrc.org>,

$<\mathrm{http}: / /$ www.southcentre.org $>$. See also reports and debates on nettime <http://www.nettime.org $>$, incommunicado $<$ http://www.incommunicado.info > and Ned Rossiter, "The World Summit on the Information Society and Organised Networks as New Civil Society Movements', in Jan Servaes and Nico Carpentier (eds), Beyond the WSIS: Towards a Sustainable Agenda for the Future Information Society, Intellect Books, Bristol, 2005 (forthcoming).

${ }^{29}$ This is a distinction Geert Lovink touches on in dialogue with Trebor Scholz in the newspaper for the Free Cooperation conference that took place in Buffalo, New York in April 2004, <http://freecooperation.org >. See Geert Lovink and Trebor Scholz, 'A Dialogue between Geert Lovink and Trebor Scholz', Free Cooperation Newspaper, 2004, p. 8. Also available at $<$ http://freecooperation.org $>$. Given his own connections with the Social Science Research Council, NYC, Lovink may well be referring to a response paper by Evan Henshaw-Plath, 'Network Technology and Networked Organizations', response paper in Information Technology and International Cooperation research stream, Social Science Research Council, New York City, 2003,

<http://www.ssrc.org/programs/itic/publications/knowledge report/memos/evan.pdf>.

${ }^{30}$ For an original study of the way in which the home computer has shaped domestic living, see Elaine Lally, Materializing Culture: At Home with Computers, Oxford and Berg, New York, 2002.

${ }^{31}$ This is the category error that so much digital architecture is prone to make. For all the rhetoric amongst contemporary architectural theorists and designers to escape the modernist iron-cage of 'form follows function', it's more often the case that a sad extension of this modernist logic as 'form follows form' occurs under the spectral wonders of digital pixels. The work of New York and Californian architects Greg Lynn and Marcos Novak are standout examples of this tendency.

${ }^{32}$ See Rossiter, 'Creative Industries, Comparative Media Theory, and the Limits of Critique from Within'.

${ }^{33}$ The hugely influential work of people such as John Fiske and Dick Hebdige in the USA, as well as others in Great Britain and Australia, has spawned countless books, essays, dissertations and postings to listserves that celebrate the 'guerilla tactics' of subcultural practices. While I can't substantiate the claim, my sense over the years is that the tendency toward a valorisation of so-called everyday tactics as oppositional politics is more pronounced within cultural studies programs and research in the USA than elsewhere. The concentration of publishers, number of universities, and size of the student and academic population in the USA would be obvious starting points to a study of this phenomenon. Someone else can do the number-crunching if they really want to. For a critique of this style of cultural studies, see Thomas Frank, One Market Under God: Extreme Capitalism, Market Populism, and the End of Economic Democracy, Anchor Books, New York, 2000.

${ }^{34}$ It will be interesting to see the extent to which the Creative Commons licence is adopted by big business-I'm guessing it'll create a suitable amount of havoc, enabling service variation and consolidate an even brighter future for the legal industry. For more information on Creative Commons-an open source style set of standards whereby some rights of authorship and intellectual production are reserved, see $<$ http://creativecommons.org $>$.

${ }^{35}$ Virno, p. 51.

${ }^{36}$ Virno, 49-51.

${ }^{37}$ Virno, p. 50.

${ }^{38}$ See Rossiter, 'Creative Industries, Comparative Media Theory, and the Limits of Critique from Within'.

${ }^{39}$ Gregory Bateson, Steps to an Ecology of Mind, Ballantine Books, New York, 1972.

${ }^{40}$ See <http://ocw.mit.edu/index.html>.

${ }^{41}$ Gilles Deleuze, 'On Gilbert Simondon', in Desert Islands and Other Texts, 1953-1974, trans. Michael Taormina, ed. David Lapoujade, Semiotext(e), New York, 2004, pp. 86-9; Virno, Grammar; Adrian Mackenzie, Transductions: Bodies and Machines at Speed, Continuum, New York, 2002; Virno, p. 76.

${ }^{42}$ See see Virno, p. 80.

${ }^{43}$ Mackenzie, p. 18.

${ }^{44}$ See Mackenzie. See also Andrew Murphie, 'The World as Clock: The Network Society and Experimental Ecologies', Topia: A Canadian Journal of Cultural Studies, no. 11, 2004, pp. 117-39. Further references to Murphie are included within the text.

${ }^{45}$ Mackenzie, p. 16-19. 
${ }^{46}$ Murphie, p. 120.

${ }^{47}$ Ulrich Beck, What is Globalization?, trans. Patrick Camiller, Polity Press, Cambridge, 2000, p. 8.

${ }^{48}$ Beck, p. 8.

${ }^{49}$ Beck, p. 9-11.

${ }^{50}$ Scott Lash, Critique of Information, Sage, London, 2002, pp. 39-48.

${ }^{51}$ David Harvey, The Condition of Postmodernity: An Inquiry into the Origins of Cultural Change, Blackwell, Cambridge, Mass., 1990.

${ }^{52}$ For a critique of Lash on this point, see Rossiter , 'Creative Industries, Comparative Media Theory, and the Limits of Critique from Within'.

${ }^{53}$ Lash, 39-40.

${ }^{54}$ Paul D Miller, Rhythm Science, MIT Press, Cambridge, Mass., 2004, p. 72.

${ }^{55}$ Michael Hardt and Antonio Negri, Empire, Harvard University Press, Cambridge, Mass., p. 294.

${ }^{56}$ Virno, p. 81.

${ }^{57}$ Virno, p. 82.

${ }^{58}$ Virno, p. 49.

${ }^{59}$ Deleuze, 'On Gilbert Simondon', p. 86.

${ }^{60}$ A comment Bifo makes in the documentary A World to Invent (2002), by Florian Schneider. For more information on the What is to be Done? series and related media projects, see <http://www.wastun.org>. For a short review of this series, see Brett Neilson and Ned Rossiter, 'Report on Creative Labour Workshop', posting to fibreculture mailing list, 30 April 2004, <http://www.fibreculture.org $>$.

${ }^{61}$ Virno, p. 43.

${ }^{62}$ See Raymond Williams, 'Communications Technologies and Social Institutions', in Raymond Williams (ed.), Contact: Human Communication and its History, Thames \& Hudson, London, 1981, pp. 226-38. See also Neilson and Rossiter. 